\title{
Spectral Uncertainties: \\ A Review of Precarity and Loss: On Certain and Uncertain Properties of Life and Work by Tadeusz Rachwal
}

Author: Tadeusz Rachwał

Publisher: Springer

Release Date: 2017

Number of Pages: 143

Edyta Lorek-Jezińska ${ }^{1}$ \& Katarzyna Więckowska ${ }^{2}$

Nicolaus Copernicus University in Torun

${ }^{1}$ lorek@umk.pl

2klew@umk.pl

Received 18 Sptember 2017; accepted 28 October 2017.

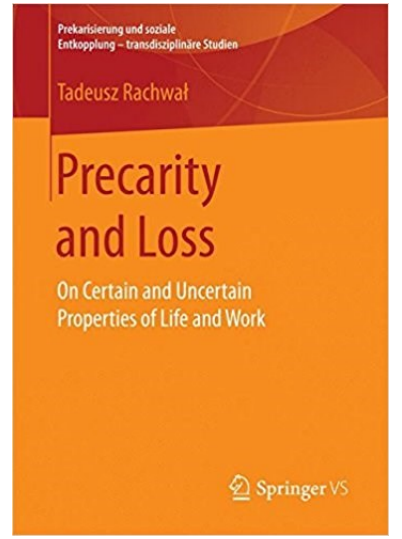

In the foreword to the 2012 edition of Liquid Modernity (first published in 2000), Zygmunt Bauman, one of the key theoreticians of the contemporary, lists "fragility, temporariness, vulnerability and inclination to constant change" as the key features of our times, when the only stable element might be described as "the growing conviction that change is the only permanence, and uncertainty the only certainty" (Bauman, 2012, p. 8; emphasis in original). The metaphor of "liquidity" aptly captures the sense of immanent but uncontrollable change and the ensuing anxieties almost universally experienced at the beginning of the $21^{\text {st }}$ century, a time of fierce globalization, authoritarian populism, rising nationalistic movements, growing separatist tendencies, constant threats of terrorist attacks targeting civilians, impelled migration, and persistently increasing poverty gap. Closely related to economic and political reconfigurations, the sense of change, insecurity and anxiety has been reinforced by the collapse of grand narratives and the loss of faith in the Enlightenment certainties of progress, science and individual identity, described by Jean-François Lyotard already in 1979. The overall result of these transformations is that in liquid modernity life itself has become "liquid," and therefore, as Bauman claims, "precarious ..., lived under conditions of constant uncertainty" (2005, p. 2). 
Precarity seems to have become one of the most frequently used terms to describe the contemporary condition, though in ways which point to various spaces and different aspects of vulnerability that is usually, but not exclusively human. Thus, Judith Butler writes about precariousness as a social and ontological phenomenon and discusses the modes in which vulnerability and the susceptibility to "arbitrary violence" are differently distributed across and between societies (2004, p. xii). ${ }^{1}$ Drawing on the work of Emmanuel Levinas, she defines precariousness as an existential category, through which one recognizes others as beings and is recognized as a being by others, and which inevitably involves facing and possibly taking on the ethical responsibility for another person's vulnerable body. While Butler's focus is on various individuals and groups to whom official discourses deny the right to being precarious - thereby denying them social, legal, or cultural recognizability-Guy Standing describes precarity as a key feature of the precariat, the new class of workers emerging under global capitalism. As presented by Standing, the precariat is a product of increasingly more unequal societies; its members experience severe deprivation and, with little help offered by the state, face the constant risk of falling into the poverty (or precarity) trap (Standing, 2014, p. 7; 2013, p. 10). The precariat are "the first emerging class to be losing all forms of rights - civil, cultural, social, economic and political" (Standing, 2016, p. 29), in effect becoming denizens rather than citizens, ${ }^{2}$ whose lives are dominated by "insecurity, uncertainty, debt and humiliation" (Standing, 2014, p. 7). Significantly, though Standing reserves the term "precariat" to designate the new working class, he also describes some general and global processes of precariatization, such as the inability to command one's time, that produce "the precariatized mind," which is "enervating and ultimately depressing because one cannot feel in control" (2013, p. 6).

Uncertainty, precarity, loss, and hesitation are the crucial themes of Precarity and Loss: On Certain and Uncertain Properties of Life and Work by Tadeusz Rachwał, which can be described as an attempt to understand precariat (Rachwał, 2017, p. viii) and to represent the many forms of contemporary precariousness experienced by "individuals orphaned from the care of the modernist fathers" (p. vii). In Rachwal's book, precarity and loss cut across many fields and texts, affecting the way of thinking about different "properties of life and work." The introduction already addresses a whole range of issues, starting from precariat and the uncertainties of employment, flexibility of life and labour and their destabilization, fragmentation as well as nomadism and ending with the concept of "the loss of loss" or spectral uncertainty. As the author admits, "this book is in a sense a hesitant book. It is also uncertain. Its hesitations result from the precarious nature of certainty itself, of the precariousness of confidence which, as we know, can always be lost. It approaches certainty with caution, wavering over making choices or certain decisions" (p. ix). Such a book is both

\footnotetext{
${ }^{1}$ In the context of the $21^{\text {st }}$-century uncertainties listed above, it should be noted that the essays collected in Butler's Precarious Life were all written "after September 11, 2001, and in response to the conditions of heightened vulnerability and aggression that followed from those events” (Butler, 2004, p. xi).

${ }^{2}$ Standing explains that "denizen" is "a medieval term used to describe those who on entering a town were given a more limited range of rights than the town's citizens" (2016, p. 29).
} 
devoted to and itself requires "slow reading," the reading that cannot be counted on to produce immediate results, that will lead the reader apparently astray, and then surprisingly return to its course to lose it again. In fact, losing the track is its intended strategy. Precarity and Loss demands from the reader time and readiness to abandon the "optimization of gain" (p. ix) and risk the loss of the thing one gains by promise - by being promised to finally and slowly reach the destination: "I will, I promise that I will, slowly arrive at the vicinities of precarity in the course of this text though, at the same time I will, after Nietzsche, go aside and take time, attempting, also at the same time, not to quite lose it" (p. ix).

Hesitation is important to Rachwał's project because the "experience of undecidability" is what "brings in, inevitably, the question of ethics, of choice hidden in the very notion of hesitation" (p. x). Accordingly, adopting the strategies of slow and hesitant deconstructive reading, the author explores various facets of precarity and uncertainty related to, among others, space, time, truth, authority, and responsibility, and examines the precarious dimensions of life, work, labour, writing, and reading. A key category in these analyses is loss, which is approached here as denoting a "loss of property" not only in the economic, but also in the epistemological sense. Reminders of the uncanny relation between economy and epistemology return at various points throughout the book, beginning with the coupling of Standing's analysis of global capitalism with Butler's inquiry into ethics, identity, and injurability. Precarity and Loss does not let its readers forget about the profoundly material parameters, corporeal or economic, of being and its descriptions, while emphasizing the power of loss that underlies these categories. In effect, Rachwat proposes to read loss in terms of spectrality, as "a spectre without origin" (p. xiv), thereby highlighting the uncertainty that permeates contemporary life and thought, and presenting it as constitutive of "the human."

Precarity and Loss: On Certain and Uncertain Properties of Life and Work is composed of an extensive introduction outlining the scope of the book and five chapters examining various discourses on uncertainty in order to assess and represent the possibilities of escaping what may be provisionally differentiated into material precarity and existential precariousness. Each of the chapters addresses a different set of questions - of what, how, why, where, and who - thereby ordering the content according to the inquiries that are basic in information gathering and problem solving. The first chapter poses the question "What?", predominantly with regard to loss as well as time, and comments on two major issues: perishability and the idea of having time. The focus in the second chapter is on "How?", particularly on how time and work are used, and on the relations between economy and aesthetics, illustrated by the discussion of, inter alia, John Ruskin's discourses on work and art, or Oscar Wilde's notion of individualism. The third chapter revisits the uncertainty in / of Descartes' writing and examines "the threat of there being nothing instead of something" that Rachwał sees as standing "behind the founding question of metaphysics asking 'Why is there something instead of nothing?" (Heidegger as cited in Rachwał, 2017, p. 51). The fourth chapter is dedicated to the question "Where?" and investigates the spaces, physical and conceptual, that answer to and oppose precarity and 
precariousness. The final chapter is a manifesto of sorts which, by addressing those subjected to precarity and precariousness, performatively re-constitutes them as subjects, turning them into a collectivity of "the Precariat; or All Together Now" (p. 105).

The first chapter, whose preoccupations centre on aspects of perishability and time, begins with references to Leonard Cohen's novel Beautiful Losers, whose protagonists, the A- $\mathrm{s}$, an imaginary, almost extinct Indian tribe, become the embodiment of absolute loss. They illustrate "the idea of life, or living, without loss, perhaps without possessing the idea of losing" (Rachwał, 2017, p. 1). But because of this, because of the impossibility of ever succeeding, they have lost their "whatness." By referring to Jean Baudrillard's commentary on the imaginary materiality of Indian reservations and factories (2007, p.19), among others, Rachwał sees Cohen's A-s as also the embodiment of perishability: "What this simulation hides is that we are all the $\mathrm{A}-\mathrm{s}$, almost extinct Indians, losers who organize work and production to hide our own 'perishability' by way of reducing its inevitability. Perishability may thus be read as a practice of 'no-whatness' something which brings to mind the 'no-placeness' of utopia . .." (Rachwał, 2017, p. 3). Perishability is discussed primarily in reference to Quentin Meillassoux's After Finitude (2008), where it is juxtaposed with contingency, but numerous other books and writers are mentioned in the discussion (inter alia Zygmunt Bauman, Marek Kwiek, Guy Standing, Jean-Luc Nancy, Raoul Vaneigem). The second part of the chapter focuses on the concept of time- of having time. The starting point of the discussion is a commentary on tertiary time and tertiary society - the terms used by Standing to describe the disappearance of the clearly marked boundaries between leisure and work, the result of which, as Rachwał argues, denotes not only the increase of precariousness but perhaps more importantly, "points to a more general condition of uncertainty which may be called the loss of 'whatness' of time along with the very possibility of its wasting, or losing, pure and simple" (p. 9). Rachwał's discussion of time, its loss or the possibility of its appropriation and possession, ordering and "timing" time, breaking it into a series of nows is primarily based on a selection of Heidegger's texts. Attempts at re-creating the past, reconstructing or recapturing it illustrate the strategies of miming what is deficient about time, as "lack is translated into loss which is itself translatable into the 'pastness' of time that may be 'had', or regained, by history" (p. 14). To abate loss, time is also "rigidified" in the stillness and permanency of tombs, architecture, paper, writing, which become the "work of mourning" (p. 16). Thus, the only time we might have is the mimetic time, its weakened double, managed by the "economies of compensation" (Derrida as cited in Rachwał, 2017, p. 18), which we delude ourselves to be able to possess and spend at will.

The second chapter asks the question "How?" and explores the uses of time and work, and thus also the possibilities of having a good life, through the concepts of poiesis, plasticity, and contingency. The author examines the attempts at limiting uncertainty, as presented in an array of critical and literary works, beginning with "the ways in which contingency may be dealt with in terms of the poetical, the realm which both escapes historical ordering and attempts to, paradoxically, extend history so as to diminish its seizing grasp" (Rachwał, 2017, p. 22). The "uses" of art-the aestheticization of contingency, labour, or 
economy - is the key issue discussed in this chapter, starting from the work of Simon Critchley and his examination of the relations between finitude and contingency, as well as fact and fiction, in particular his delineation of "facticity of fiction, and thus also of contingency of facticity" which may make it possible to think of a world "in which uncertainty does not stand in opposition to any absolute certainty of the permanence of being" (p. 23). The connections between life and art are further explored with reference to Jacques Rancière's concepts of politics and aesthetics, and his notion of dissensus which reveals the contingency of a particular social arrangement, or what Rancière calls the " "partition of the sensible' in which art does not simply transform messages, but partitions spaces and times defining ways of being together or apart" (p. 23). It is in this context that Rachwat reads Oscar Wilde's project of "oppositional" aestheticism and Individualism as an attempt of getting rid of both the precariat and precariousness (p. 25), and discusses William Morris's proposal of "work-pleasure" as a dissensual activity (pp. 26-27). 19 $9^{\text {th }}$-century discourses on society, work, and art offer some enduring answers to the question of how one should work, labour, and live - aesthetically according to Wilde, pleasantly and industriously according to John Ruskin, or, as the analysis of Charles Dickens's Hard Times proves, in a disciplined and disciplinary manner. What underlies most of these concepts, as Rachwał states, is the "annexation" of work and nature by labour, which can be traced back to John Locke, in whose writings the ability to work is intricately bound with property and possession not only of one's self or body, but also of one's land, and in which "being" is transformed "into having through labour" (pp. 37-42). The chapter finishes with a return to Heidegger's notion of dwelling to read it through the Greek idea of poiesis and to argue for the "originary uncertainty of poetic dwelling" which "questions the security of the dwelling place, of broadly understood home which turns out to be an inevitably haunted place, a place which is open to the contingent spirit of the undecidability of language, of its always provisional status" (p. 45).

Chapter 3, "Why? Something, Nothing and (Descartes') Uncertainty" starts with Heidegger and Hamlet. Addressing the Heideggerian query of "Why are there beings at all instead of nothing?"(Heidegger as cited in Rachwał 2017, p. 52), Rachwał develops his commentary on consequences of questioning beings and questioning also the very act of questioning itself (Heideggerian "Why the Why?"). The fact that this question is additionally "hamletized" by Heidegger is the beginning of reflections on the nature and possibility of choice which in a way the "why?" question eliminates. Hamlet, who is suspended in his inability to choose, belongs to the pre-political world in which such a sovereign choice based on the presence of the sovereign identity, as Rachwał argues, referring to Carl Schmitt's analysis of Hamlet and its embedding in the political situation of the times of its creation, is not yet possible, for he "does not know nothing" (p. 55) and Hamlet's "question, and choice, can be made only by one holding the power to except" (p. 56). The power to except and relegate to nothingness is considered in relation to Agamben's concept of homo sacer and "bare life" and other implications of exteriorization and our vulnerability to exclusion (e.g. Deleuze and Guattari). What emerges out of this discussion is the very plasticitymutability — of being or being as mutability, discussed extensively in relation to Catherine 
Malabou's writing, the category that seems to go beyond the choice between being and nothingness and beyond death. Following the strategy of "going aside and taking time," Rachwał reflects on how the field of translation is affected by the category of loss, which comes to replace lack (Slavoj Žižek) and how its authenticity is linked to the precariousness of both the authority of the original and the position of the translator as a copier (p. 65). ${ }^{3}$ In the last part of the chapter Rachwał moves to the third element of the title, Descartes, whose "cogito ergo sum" "has been historically marked as one of the beginnings of modernity (along with its faiths in permanence and certainty)," to argue that "what it in fact establishes is a certain dynamism of constant deference of the uncertain as constitutive of the fragile position of the thinking subject" (pp. 75-76). In order to preserve certainty and offset uncertainty, which are the aims Descartes sets to himself and human beings in general, what is required, it seems, is a constant erasure of the past: "Since more or less everything seems to be erroneous, certainty needs a new beginning which erases all the traces of the old, a writing under at least double erasure which erases the erased, perhaps a flood or deluge of sorts after which the creation will be repeated. This repetition, importantly, must not remember the old, must not be able to refer the old as lost, not even as a lost paradise" (pp. 80-81). Rachwał's extensive critique of Descartes' certainty concludes with Žižek's commentary on the loss of loss, which posits the possibility of reading loss in positive and productive categories, as creating "a space of incessant reconfiguration of the world" (p. 87).

The question of "Where?" is addressed in Chapter 4, which focuses on the relations between places and spaces, or more specifically on what Rachwał calls "spacing places," and discusses the ideas, projects, books, writers, and artists that make such spacing possible. "Spacing places" is both "a strategy of rethinking space" (p. 95) and "an idea that questions, among others, the scope of finitude" (p. 92), which the author juxtaposes against "placization," that is, "a reduction of space to place" that makes the former finite (p. 90). This reduction is a crucial aspect of the power of capitalism (p. 90), hence questioning finitude is also a search for spaces, physical, architectural and conceptual, that oppose the system. Unlike scholars such as J.K. Gibson-Graham, ${ }^{4}$ who look for this kind of spaces outside capitalism, Rachwał argues against the illusion of exteriority and claims that it is "within capitalism that the allegedly new enterprises and spaces should be built" (p. 90). The examples of such spaces discussed in the chapter include Constant Nieuwenhuys's New Babylon, a radical, anti-capitalist project of nomadic urbanity and identity which "slightly blurs the division into the made and the maker" and the conventional division of labour (p. 92); Yona Friedman's concept of mobile architecture, most famously embodied in his project of The Spatial City, which gives a new kind of mobility to the inhabitants (p. 101); or, on a more abstract level, Rosi Braidotti's "nomadic eco-philosophy of belonging” (p. 93). In such places, spacing functions in a manner similar to that described by Jean-Luc Nancy as

\footnotetext{
${ }^{3}$ The concept of authenticity is associated with precariousness in a variety of contexts which Rachwał further discusses: Barthes' intertextuality, Bloom's anxiety of influence, or Baudrillard's reproducibility of all objects.

${ }^{4}$ Interestingly, this is a pen name adopted by feminist economic geographers Julie Graham and Katherine Gibson, which provides another area of uncertainty by questioning the conventional approach to the figure of the Author.
} 
opening "a new horizon of unheard-of identities" (Nancy cited in Rachwał, 2017, p. 7) and producing places of an almost "poetical" dwelling in an uncoordinated environment. While the utopian projects of Friedman and Constant may seem "naïve ways of mapping and orienting the world," they also, as Rachwał argues, provide spaces where "loss is not relationally attached to gain, or achievement," and whose dwellers may "unlearn the abstract" so as to learn "what it really means to love thy neighbour" (pp. 103-104).

The questions of neighbouring and neighbours, or of "being-building-neighbouring" (p. 106), occupy the central space in the final section of the book which, as a way of concluding, considers the "who" of the precariat and its possibilities of action. The chapter juxtaposes neighbouring, considered as Heideggerian "dynamic kind of poetic dwelling" and Derridean hospitality of "neighbours awaiting neighbours as guests" (p. 106), against the notion of individuality which Rachwał, following Friedrich Hayek, sees as "a selfcliquing care for the self in which building can be only seen as . . extensions of the defensive measures and means" (p. 107), as a closure, not an opening. Referring to the work of Alain Badiou and Luce Irigaray, the chapter introduces the concept of "love" into the notion of collectivity in order to reconfigure the "we" of "the precariat" into "a kind of togetherness in which lack is not a sign of a precarious position, a sign of loss, but an attitude which is lovingly, though perhaps painfully assumed" (p. 109). This attitude is based on the acceptance of ambivalence and uncertainty, so that the rise of the precariat may become "an opening of the threshold, of the space in which we begin to re-think difference and togetherness, and to realize that the complex senses of us and them need not be normalized, and that we and them may, and must, lovingly mix at the thresholds of what we are" (p. 113). As Rachwał argues, it is this ambivalence, "this potential to transform and change," and "this spectre of changeability in non-belonging" that make the precariat a precarious and "dynamically plastic kind of being" (p. 114). In the end, "We the Precariat" constitutes a threshold and "a somehow naïve world governed by the law of the real which . . is the law of love" and by an economy "which will have left the economy of loss and debt, as it were, at its home" (p. 114).

Tadeusz Rachwał's Precarity and Loss is concerned with what to many people has become an everyday experience of the $21^{\text {st }}$-century life and work. It is an important book for its ability to combine this lived experience of uncertainty with reflection on its various implications, which — while they perhaps cannot reduce the anxiety related to precarity — can make the experience understandable and productive, creating space, or spacing places, for a new kind of collectivities. One of these productive implications of Rachwal's book is finding a way out of the necessity to know for certain, of writing and acting without having to know, which might be seen as a response to Bauman's description of modernity as anxious and uncertain. In the preface to the 2012 edition of Liquid Modernity, with which we have begun our review, the sociologist returns to Antonio Gramsci's concept of the interregnum as the period when "the old is dying and the new cannot be born" (Gramsci,

\footnotetext{
${ }^{5}$ Rachwał refers here to Michel Serres's declaration from The Natural Contract that "There is nothing real but love, and no other law" (p. 50).
} 
1978 , p. 276) to describe the early $21^{\text {st }}$ century as the time "when the old ways of doing things no longer work, the old learned or inherited modes of life are no longer suitable for the current conditio humana, but when the new ways of tackling the challenges and new modes of life better suited to the new conditions have not as yet been invented, put in place, and set in operation" (Bauman, 2012, p.vii). Bauman's acknowledgment of the suspension of time, of its tense hesitation, is also a call for a different strategy of thinking, writing, and doing things, to which Rachwał's book responds, though necessarily "only with a certain uncertainty, hesitantly" (Rachwał, 2017, p. ix), by making "spectral uncertainty ... one more 'property of life', both certain and uncertain, a property which, like life, cannot be protected by a "now' which testifies to its simple presence" (p. xv).

\section{References}

Baudrillard, J. (2007). Symbolic exchange and death. (I. H. Grant, Trans.) Los Angeles, CA: Sage Publications.

Bauman, Z. (2005). Liquid life. Cambridge, UK: Polity.

Bauman, Z. (2012). Liquid modernity. Cambridge, UK: Polity.

Butler, J. (2004). Precarious life: The powers of mourning and violence. London, UK: Verso.

Gramsci, A. (1978). Selections from the Prison Notebooks of Antonio Gramsci. (Q. Hoare \& G. Nowell-Smith, Eds.). London, UK: Lawrence \& Wishart.

Lyotard, J.-F. (1984). The postmodern condition: A report on knowledge. (G. Bennington \& B. Massumi, Trans.). Manchester, UK: Manchester University Press.

Rachwał, T. (2017). Precarity and loss: On certain and uncertain properties of life and work. Wiesbaden, Germany: Springer VS.

Serres, M. (2003). The natural contract. (E. MacArthur \& W. Paulson, Trans.). Ann Arbor: University of Michigan Press.

Standing, G. (2013). Tertiary time: The precariat's dilemma. Public Culture, 25(1), 5-23.

Standing, G. (2014). The precariat: The new dangerous class. London, UK: Bloomsbury.

Standing, G. (2016). The precariat dilemma. In Y. Cooper (Ed.), Changing work: Progressive ideas for the modern world of work (pp. 25-31). London, UK: Fabian Society. 